\title{
Journal of Bacteriology and

\section{Detection of Salmonella in Food Samples by Culture and Polymerase Chain Reaction Methods}

Omar B Ahmed ", Atif H Asghar, Ibrahim HA Abd El-Rahim and Hegazy Al

Department of Environmental and Health Research, The Custodian of the Two Holy Mosques Institute for Hajj and Omraa, Kingdom of Saudi Arabia

*Corresponding author: Omar Bashir Ahmed, Department of Environmental and Health Research, The Custodian of the Two Holy Mosques Institute for Hajj and Omraa, Kingdom of Saudi Arabia, Tel: 966125572855; E-mail: abuaglah1@hotmail.com

Rec date: Apr 04, 2014; Acc date: May 02, 2014; Pub date: May 5, 2014

Copyright: () 2014 Ahmed OB, et al. This is an open-access article distributed under the terms of the Creative Commons Attribution License, which permits unrestricted use, distribution, and reproduction in any medium, provided the original author and source are credited.

\begin{abstract}
Conventional culture methods for the isolation and identification of food borne bacterial pathogens are rather sensitive and quite inexpensive, but at the same time they are labor-intensive and time-consuming. Molecular techniques are more rapid and highly sensitive for identification of food pathogens. This study was carried out to evaluate a 12 hour PCR method for detection of Salmonella in food samples. The results showed that out of 150 food samples, $32(21.3 \%)$ were positive by culture, $35(23.3 \%)$ were positive by PCR, the sensitivity of PCR was $100 \%$ while specificity was $97.5 \%$. The study concluded that the 6 -h enrichment followed by PCR was rapid, simpler method that allowed the detection of Salmonella spp. within a maximum of $12 \mathrm{~h}$.
\end{abstract}

Keywords: Salmonella; PCR; Enrichment; Culture methods; Food samples

\section{Introduction}

Food poisoning is defined as any disease of an infectious or toxic nature caused by the consumption of food or beverages that are contaminated with harmful microorganisms, such as certain bacteria viruses or parasites [1]. Salmonella is a Gram-negative, usually motile, facultative anaerobic, flagellated rod-shaped. Salmonella enteritidis has become the most common cause of salmonellosis which is the second major cause of foodborne disease acquired in the United States and leads episodes of hospitalization and death $[2,3]$.

Conventional culture methods have traditionally been considered as the "gold standard" for the isolation and identification of foodborne bacterial pathogens [4]. They consist of a series of steps that include nonselective enrichment, selective enrichment, selective/differential plating and, finally, morphological, biochemical and serological confirmation. This standardized classical culture method is known to be sensitive and inexpensive, but culture methods are labor-intensive and time-consuming, because they require at least, three working days to produce a negative result and five to ten working days for confirmed positive results. Moreover, due to environmental factors, variations in gene expression of microorganisms can occur and may affect the results of biochemical tests. Furthermore, viable but noncultivable cells are not detected by the conventional methodology [5]. Rapid methods for the detection of Salmonella in food have been developed, for example, electrical techniques, immunoassays and nucleic acid probe analyses [3], but there are still problems with their sensitivity and specificity.

The PCR represents a rapid procedure with high sensitivity and specificity for the immediate detection and identification of specific pathogenic bacteria from different food materials [6-8]. But PCR can be limited by several factors (e.g. food components, humic acid, urine, bile salts, etc) [3]. The low number of pathogens occurring heterogeneously within a relatively large volume of food and inhibition of PCR by the food matrix is a main limitation factor. Moreover, in cases where a pathogen is detected, the conventional method must be used for confirmation [4]. The removal of the inhibitory substances is a major step in the preparation of the samples for PCR based detection of food pathogens. Although these inhibitory substances limit the application of PCR directly to food samples, the application of PCR based assays to enrichment broths has been more successful [9]. This study was carried out to evaluate a rapid (12 hour) method for detection of Salmonella in food samples and compare it with the conventional method.

\section{Materials and Methods}

One hundred and Fifty food samples of meat, comprising beef ( $n=64)$, chicken $(n=80)$, and fish $(n=6)$. Samples were suspected to be contaminated with Salmonella. All samples were labeled, recorded and were analyzed as soon as possible. If delayed, samples would be refrigerated on $0-4^{\circ} \mathrm{C}$ for not more than $24 \mathrm{~h}$ after collection. The preenrichment of samples was performed according to the method described by Medici et al., [10] with some modification. About $25 \mathrm{~g}$ samples were homogenized with $225 \mathrm{~mL}$ of Buffered Peptone Water (BPW) medium(Oxoid, CM0509) and then divided into two aliquots. The first aliquot was subjected to pre-enrichment culture for 6 hour while the second one was incubated at $37^{\circ} \mathrm{C}$ for $24 \mathrm{~h}$. The first aliquot was subjected to DNA extraction by boiling method and the second aliquot was used to confirm the presence of Salmonella by standard cultural method, and followed by biochemical and serological confirmatory tests.

Preparation of template DNA samples was performed by boiling method. One $\mathrm{mL}$ of the pre-enriched first aliquot sample was transferred to a $1.5 \mathrm{~mL}$ micro-centrifuge tube and centrifuged for 10 $\min$ at $14,000 \times \mathrm{g}$. The supernatant was discarded carefully. The pellet was re-suspended in $300 \mu \mathrm{L}$ of DNase-RNase-free distilled water by vortexing. The tube was centrifuged at $14,000 \times \mathrm{g}$ for $5 \mathrm{~min}$, and the supernatant was discarded carefully. The pellet was re-suspended in $200 \mu \mathrm{L}$ of DNase-RNase-free distilled water by vortexing. The microcentrifuge tube was incubated for $15 \mathrm{~min}$ at $100^{\circ} \mathrm{C}$ and immediately 
chilled on ice. The tube was centrifuged for $5 \mathrm{~min}$ at $14,000 \times \mathrm{g}$ at $4^{\circ} \mathrm{C}$ The supernatant was carefully transferred to a new micro-centrifuge tube and an aliquot of $10 \mu \mathrm{L}$ of the supernatant was used as the template DNA in the PCR.

PCR was done as follows: A $50 \mu \mathrm{l}$ PCR mixture contained a $5 \mu \mathrm{l}$ of DNA template, $1 \mu \mathrm{l}(100 \mathrm{pmol})$ of each primer and a $25 \mu \mathrm{l}$ of Taq PCR Master Mix polymerase containing $100 \mathrm{mM}$ Tris- $\mathrm{HCl}, 500 \mathrm{mM} \mathrm{KCl}$ at $\mathrm{pH} 8.3$ at $20^{\circ} \mathrm{C}, 1.5 \mathrm{mM} \mathrm{MgCl}_{2}, 200 \mathrm{M}$ each deoxyribonucleoside triphosphate and $0.025 \mathrm{U}$ Taq polymerase (Qiagen, USA). Amplification of DNA was performed using Mastercycler personal PCR machine. heat denaturation at $95^{\circ} \mathrm{C}$ for $5 \mathrm{~min}$, followed by 35 cycles $\left(90 \mathrm{~s}\right.$ at $95^{\circ} \mathrm{C}, 60 \mathrm{~s}$ at $62^{\circ} \mathrm{C}$, and $90 \mathrm{~s}$ at $72^{\circ} \mathrm{C}$ ), and an elongation step of $7 \mathrm{~min}$ at $72^{\circ} \mathrm{C}$. The primers used were Salm3 (5'GCTGCGCGCGAACGGCGAAG-3') and Salm4 (5'TCCCGGCAGAGTTCCCATT-3'), which amplify a 389-bp fragment within the conserved invA gene sequence of Salmonella spp. [11]. Data of culture and PCR results were tested for correlation (spearman, s rho) and analyzed by computer using Statistical Package for Science (SPSS) version 21 program.

\section{Results}

The results showed that out of 150 food samples, 32 (21.3\%) were positive by culture, $15 / 64(23.4 \%)$ were beef meat while $15 / 80(18.6 \%)$ were chicken meat and $2 / 6(33.3 \%)$ were fish meat. Also out of 150 food samples, 35 (23.3\%) were positive by PCR, 16/64 (25\%) were beef meat while $17 / 80$ (21.3\%) were chicken meat and 2/6 (33.3\%) were fish meat as shown in Figure 1. When culture was considered as golden standard, the sensitivity of PCR was $100 \%$ while specificity was $97.5 \%$ with positive predictive value (PPV) and negative prdictive value (NPV) $91.4 \%$ and $100 \%$ respectively. Statistically there was strong correlation (0.954) between PCR and culture. Correlation is significant at the p-value (0.01) level.

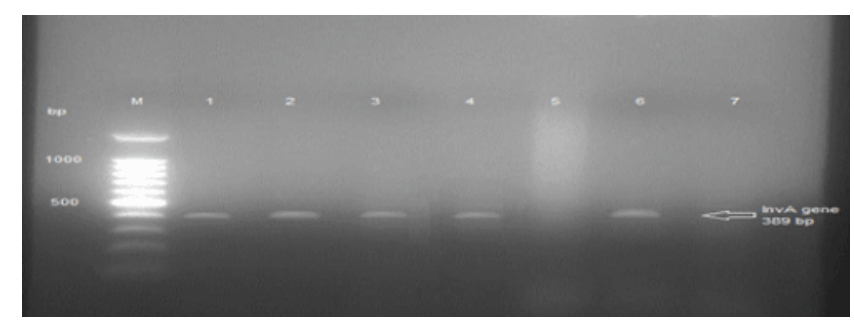

Figure 1: The invA gene after PCR on $2 \%$ agarose gel electrophoresis. Lane M: 100-bp DNA ladder. Lane 1: Control positive. Lanes 2, 3, 4, and 6: positive invA gene of Salmonella strains (389 bp). Lane 5: negative invA gene of Salmonella strains. Lane 7: control negative.

\section{Discussion}

The increased frequency of food-borne Salmonella has been causing recurring outbreaks, sometimes with fatal infections. Most infections result from the ingestion of foods of animal origin contaminated with Salmonella species such as beef, chicken, shellfish, eggs, and milk [12-14]. The routine detection of Salmonella in foods is a important part of public health programs because the presence of Salmonella in food can cause health problems. In this study 150 food samples (suspected to be contaminated with salmonella) were tested for presence of Salmonella by two different methods, culture and PCR. The culture results showed that $21.3 \%$ of the total samples were positive; the contamination of beef meat by Salmonella was $23.4 \%$ while chicken meat was $18.6 \%$ and fish meat was $33.3 \%$. Cultural methods are based on nutrient acquisition, biochemical characteristics, and metabolic products unique to Salmonella spp [15]. However, the cultural methods require multiple sub-culturing stages followed by biochemical and serological confirmatory tests, which can take up to 7 days to get a confirmed positive result. Molecular screening methods have been also used to detect nucleic acids. In this study, we used a rapid and simpler method proposed by Ferretti et al. [16] that relying on a 6-h nonselective enrichment in BPW followed by cell breaking and PCR to detect Salmonella spp. within a maximum of 12 hour from the receipt of food samples. Pre-enrichment culture has been done in order to increase the viable number of Salmonella in the samples prior to the detection of Salmonella by PCR technique. We found that the number of samples detected by PCR using genomic DNA obtained by boiling method from contaminated food samples had been raised to $23.3 \%$., $16 / 64(25 \%)$ were beef meat while $17 / 80$ (21.3\%) were chicken meat and $2 / 6(33.3 \%)$ were fish meat. When culture was considered as golden standard, the sensitivity of PCR was $100 \%$ while specificity was $97.5 \%$ with PPV and NPV of $91.4 \%$ and $100 \%$ respectively. This result proved the specificity of $12 \mathrm{~h}$ preenrichment-PCR. The $12 \mathrm{~h}$ pre-enrichment-PCR procedure could offer a rapid and good diagnostic tool for the routine monitoring of detection of Salmonella in food samples compared to the conventional culturing method. Other studies have also reported that the use of a PCR assays were more sensitive than the culture method for detecting Salmonella in food, especially in poultry, meat, and poultry related products [17-21]. In this study we used a method proposed by Ferretti et al. [16] who applied a PCR method without Internal Amplification Control (IAC), and although similar studies have been published previously [17-21], but PCR could be improved by introduction of a general IAC to prevent the occurrence of false negative results and to control the effects of inhibiting agents on amplification efficiency $[22,23]$.

Finally our findings indicated that the 6-h enrichment followed by PCR was rapid and simple method that allowed the detection of Salmonella spp. within a maximum of $12 \mathrm{~h}$ from the receipt of food samples.

\section{References}

1. Mead PS, Slutsker L, Dietz V, McCaig LF, Bresee JS, et al. (1999) Foodrelated illness and death in the United States. Emerg Infect Dis 5: 607-625.

2. Scallan E, Hoekstra RM, Angulo FJ, Tauxe RV, Widdowson MA, et al. (2011) Foodborne illness acquired in the United States--major pathogens. Emerg Infect Dis 17: 7-15.

3. Jeníková G, Pazlarová J, Demnerová K (2000) Detection of Salmonella in food samples by the combination of immunomagnetic separation and PCR assay. Int Microbiol 3: 225-229.

4. Jasson V, Jacxsens L, Luning P, Rajkovic A, Uyttendaele M (2010) Alternative microbial methods: An overview and selection criteria. Food Microbiol 27: 710-730.

5. Malorny B, Tassios PT, Rådström P, Cook N, Wagner M, et al. (2003) Standardization of diagnostic PCR for the detection of foodborne pathogens. Int J Food Microbiol 83: 39-48.

6. McKillip JL, Drake M (2004) Real-time nucleic acid-based detection methods for pathogenic bacteria in food. J Food Prot 67: 823-832. 
Citation: Ahmed OB, Asghar AH, Abd El-Rahim IH and Hegazy Al (2014) Detection of Salmonella in Food Samples by Culture and Polymerase Chain Reaction Methods. J Bacteriol Parasitol 5: 1000187. doi:10.4172/2155-9597.1000187

Page 3 of 3

7. Lantz P G, Hahengerdal B, Radstrom P (1994) Sample preparation methods in PCR-based detection of food pathogens. Trends in food science and technology 5: 384-389.

8. Hill WE (1996) The polymerase chain reaction: applications for the detection of foodborne pathogens. Crit Rev Food Sci Nutr 36: 123-173.

9. Lampel KA, Orlandi PA, Kornegay L (2000) Improved template preparation for PCR-based assays for detection of food-borne bacterial pathogens. Appl Environ Microbiol 66: 4539-4542.

10. De Medici D, Croci L, Delibato E, Di Pasquale S, Filetici E, et al. (2003) Evaluation of DNA extraction methods for use in combination with SYBR green I real-time PCR to detect Salmonella enterica serotype enteritidis in poultry. Appl Environ Microbiol 69: 3456-3461.

11. Rahn K, De Grandis SA, Clarke RC, McEwen SA, Galán JE, et al. (1992) Amplification of an invA gene sequence of Salmonella typhimurium by polymerase chain reaction as a specific method of detection of Salmonella. Mol Cell Probes 6: 271-279.

12. D'Aoust JY (1997) In Food Microbiology. Fundamentals and Frontirers (eds. Doyle, M.P., Beuchat, L.R., and Montville, T.J.) ASM Press, Washington.

13. D'Aoust JY (2000) In The Microbiological Safety and Quality of Food, Volume II (eds. Lund, B.M., Baird-Parker, T.C., and G. W. Gould) Aspen Publishers, Inc, Gaithersburg, Maryland.

14. Olsen SJ, MacKinnon LC, Goulding JS, Bean NH, Slutsker L (2000) Surveillance for foodborne-disease outbreaks--United States, 1993-1997. MMWR CDC Surveill Summ 49: 1-62.

15. Ricke SC, Pillai SD, Norton RA, MAciorowski KG, Jones FT (1998) Applicability of rapid methods for detection of Salmonlla spp. in poultry feeds: a review. Journal of Rapid Methods and automation in Microbiology 6: 239-258.
16. Ferretti R, Mannazzu I, Cocolin L, Comi G, Clementi F (2001) Twelvehour PCR-based method for detection of Salmonella spp. in food. Appl Environ Microbiol 67: 977-978.

17. Bennett AR, Greenwood D, Tennant C, Banks JG, Betts RP (1998) Rapid and definitive detection of Salmonella in foods by PCR. Lett Appl Microbiol 26: 437-441.

18. Eyigor A, Carli KT, Unal CB (2002) Implementation of real-time PCR to tetrathionate broth enrichment step of Salmonella detection in poultry. Lett Appl Microbiol 34: 37-41.

19. Fratamico PM (2003) Comparison of culture, polymerase chain reaction (PCR), TaqMan Salmonella, and Transia Card Salmonella assays for detection of Salmonella spp. in naturally-contaminated ground chicken, ground turkey, and ground beef. Mol Cell Probes 17: 215-221.

20. Oliveira SD, Santos LR, Schuch DM, Silva AB, Salle CT, et al. (2002) Detection and identification of salmonellas from poultry-related samples by PCR. Vet Microbiol 87: 25-35.

21. Whyte P, Mc Gill K, Collins JD, Gormley E (2002) The prevalence and PCR detection of Salmonella contamination in raw poultry. Vet Microbiol 89: 53-60.

22. Hoorfar J, Ahrens P, Rådström P (2000) Automated 5' nuclease PCR assay for identification of Salmonella enterica. J Clin Microbiol 38: 3429-3435.

23. Raggam RB, Leitner E, Mühlbauer G, Berg J, Stöcher M, et al. (2002) Qualitative detection of Legionella species in bronchoalveolar lavages and induced sputa by automated DNA extraction and real-time polymerase chain reaction. Med Microbiol Immunol 191: 119-125. 